\title{
EFFECT OF NURSING COUNSELING ON CONTINUATION RATE OF USING INTRA UTERINE DEVICE
}

\section{Prof. Ragaa Ali Abd Raboo, Assist.Prof. Seham Shehata Ibrahim, Dr. Norelhoda Mohamed Elsayed, Eman Abd-Elfatah Ali Alosta}

Prof of maternal and newborn health nursing, Faculty of Nursing-Cairo University, Assistant prof of Maternity, Obstetrics and Gynecological Nursing, Faculty of Nursing - Port said University, Lecturer of Maternity, Obstetrics and Gynecological Nursing, Faculty of Nursing - Port said University.

\begin{abstract}
Background: Intrauterine device is the most commonly used method of long-acting reversible contraception. Aim: The aim of the present study is to; assess the effect of nursing counseling on the continuation rate of using intra uterine device Subjects and Method: Design: a quasi-experimental design was used in this study. Setting: Study carried out at six primary health care centers in Damietta governorate in Damietta city. Subjects: A total of 150 women who attended family health centers for IUD insertion were purposively selected and divided to two group; control and study group. Tools of data collection: It includes; structured interview with pre and post test, and Follow up test. Results: The current study shows that the majority of women in both study and control group (96\%) and (90\%) respectively continued use of IUD. Counseling was associated with statistically significant improvement in women's knowledge. Conclusion: The majority of women in both control and study group continued using IUD after six months from receiving counseling. The main reason for discontinuation in the study group was husband travel but in control group was side effect. Counseling was associated with statistically significant improvement in women's knowledge regarding IUD. Recommendations: continuous training of health providers to provide good family planning services, continuous information provision and counseling to the women, especially on the side effects.
\end{abstract}

Key words: Counseling, Discontinuation, Intrauterine device, Un planned pregnancy. 


\section{INTRODUCTION}

The desire for smaller families and the capacity to time pregnancies and space births have increased dramatically in developing countries over the past three decades (Ali et al., 2012), Despite these increases, many women using family planning discontinue their contraceptive method and without switching to another method, despite their desire to avoid pregnancy.

Analyses of Demographic and Health Survey (DHS) data indicate that $38 \%$ of women with an unmet need for modern contraception have used a modern method of contraception in the past but have chosen to discontinue use. This phenomenon called contraceptive discontinuation, is defined as starting contraceptive use and then stopping for any reason while still at risk of an unintended pregnancy (Castle \& Hardtman, 2015). High levels of discontinuation can adversely affect the impact of family planning programs (Jain et al., 2013).

Intrauterine device is the most commonly used method of long-acting reversible contraception because of its high efficacy, safety, ease of use, and low cost (Dean\& Goldberg, 2016). IUD is used worldwide by an average of 23 percent of female contraceptive users, and 30 percent of female contraceptive users in Egypt (Egypt Demographic and Health Survey, 2014).

Although IUD is one of the safest and the most widely used reversible contraceptive methods, complications such as bleeding and pain lead to early removal of IUD in some cases, leaving them exposed to the risk of an unintended pregnancy, so health care providers should give more emphasis to counseling programs for women desiring IUD insertion( Manzouri et al ., 2011)

\section{SIGNIFICANCE OF STUDY:}

Millions of women want to use safe and effective family planning methods, but they aren't able to do due to lack of access to information and services. Although IUD is a highly effective, safe, private, long-acting, and rapidly reversible method of contraception with few side effects, complications such as bleeding and pain lead to early discontinuation. The Recent researches in Egypt found that incidence of using IUD is decline about $17 \%$ from (2008-2014), By identifying the causes of contraceptive methods discontinuation and Counseling about the selection of the method, potential 
causes can be prevented and the continuation rate can be increased. So it's important to assess the impact of nursing counseling on continuation rate of IUD. Moreover, providing information to the women about the selected method prior to use it, was significantly associated with high client satisfaction and higher continuation rates.

\section{AIM OF STUDY:}

The aim of the present study was to; assess the effect of nursing counseling on the continuation rate of using intra uterine device

\section{SUBJECTS AND METHOD:}

\section{A. Technical design:}

This design covers the research design, settings, subjects and tools of data collection.

\section{Research design:}

A quasi-experimental design was used for this study to achieve the stated aim.

\section{Study setting:}

The present study was carried out in six primary health care centers in Damietta governorate; (Mubarak center and Almarkaz Alteby Alam) in New Damietta, (Alsenania, Almontazah, Hay Awal and Hay Tani) in Damietta city, this gave the chance to the researcher to collect necessary information.

\section{Study sample:}

A purposive sample of patients who attended the study setting and fulfilling the following inclusion were recruited for this study.

\section{Inclusion criteria:}

- At the reproductive age.

- Those attending family health centers for IUD insertion.

- Woman accept to participate in the study.

\section{Sampling technique:}

A purposive sampling technique was followed in selecting 150 women who attended the previously mentioned study setting for IUD insertion. Sample divided into study and control group This was continued until the required sample size was fulfilled.

\section{Tools of data collection:}

Tool (I): A structured interview schedule. It was utilized by researcher to collect the 
necessary data. It entailed three parts:

Part 1. This includes;

- Personal and socio-demographic characteristics about the study subjects such as (age, level of education and occupation ....etc).

- Menstrual history: which include age of menarche, regularity, amount of menstrual blood, duration of bleeding and presence of dysmenorrhea.

- Obstetric history such as gravida, Para, abortions,...etc.).

- A detailed medical, surgical, family and gynecological history were also obtained.

- Data related to the previously used IUD such as the reason for IUD discontinuation and the husband's opinion of IUD.

\section{Part 2. Pre and Post knowledge about IUD:}

This tool was developed by researcher to assess women's knowledge about IUD (source of knowledge about IUD, action, types, advantages, side effects, suitable time for IUD insertion and follow up).

\section{Part 3. Follow up Sheet:}

To follow participant for continuation of IUD after six months from having counseling on it, reason for discontinuation and intended use family planning method.

\section{Scoring system:}

For the knowledge items, a correct response was scored 1 and the incorrect zero. The items were summed up and the total divided by the number of the items, giving a mean score for the part. The scores were converted into a percent score, means and standard deviations were computed. Knowledge will consider satisfactory if the percent score $60 \%$ or more and unsatisfactory if less than $60 \%$.

\section{B- Administrative design:}

An official permission was granted by submission of an official letter from the Faculty of Nursing to the responsible authorities of the study setting (Director of Primary Health Centers in Damietta) to obtain their permission for data collection.

\section{C- Operational design:}


The operational design includes preparatory phase, tools validity, reliability, pilot study and fieldwork.

\section{C.1-Preparatory phase:}

The preparatory phase aimed to prepare the tools used in data collection. During this phase, the researcher reviewed local and international literature, different studies and theoretical knowledge of various aspects of the research topic using books, articles, internet, periodicals and magazines to get more knowledge about the study subject. This also helped in designing the study tools.

\section{C.2-Tools validity:}

Five experts in the field of obstetrics and gynecological nursing and medicine tested the tools for content validity. The recommended modifications were done and the final form was ready for use.

\section{C.3- Reliability:}

Alpha Cronbach reliability analysis for the study tool was done. It revealed that question statement of the tool were relevance.

\section{C.4-Pilot study:}

The pilot study was carried out over a period of one month. It was conducted on $10 \%$ of the total sample size to evaluate the reliability and applicability of tools and to estimate the proper time required for answering the questionnaire. Necessary modifications were carried out as revealed from the pilot study. The study tool was revised, redesigned and rewritten according to obtained results and acceptance of final form. woman's who included in pilot study were excluded from study sample.

\section{B.5-Field of work:}

Data collected through a period of nine months from the beginning of January 2017 to the end of September 2017. The researcher started the data collection during the six days of the week. Three days were permitted for each center alternately. The researcher interviewed women who came for IUD insertion.

\section{The data were collected according to the following phases:}

\section{I- Assessment phase (pre test):}

After obtaining the permission from the director of the center, the researcher introduced herself to the woman in the waiting room, explained the purpose of the study to her and asked for her oral consent to participate in the study. Participants divided into two groups (study group) and (control group). As for the study group, The researcher interviewed each women individually using the interview sheet. The researcher started by obtaining data related to socio-demographic, obstetric history, previous use of 
contraception. This was followed by assessment of knowledge about IUD. The sheet was filled by researcher, Each woman takes approximately thirty minutes for filling the sheet with total number between four to five women per day. The researcher was available three days per week in the study settings alternatively.

\section{II- Implementation phase of IUD counseling:}

After finishing the assessment phase, researcher started to implement IUD counseling . The program was developed in clear and concise form and focused on the point of learning, using different teaching methods such as discussion, demonstration . a booklet was prepared by researcher, it included all information about IUD (The types, mode of action, efficacy, advantages, disadvantages, side effects, contra indications, suitable time for IUD insertion and follow up were all included). it was distributed to the participants to see pictures and listen to illustration from the researcher .

\section{III- Evaluation phase ( post test):}

After two months, telephone contact was done to each women to assess the women's knowledge about IUD (post test) and another telephone contact was done after six months to assess the continuation rate of IUD and any problem occurred during using it.

On the other hand, the control group was interviewed for collecting the sociodemographic, clinical data and pretest but there is no counseling introduced to them. After six months, telephone contact was done to assess the continuation rate of IUD and any problem occurred during using it.

Pre and post test questions related to women's knowledge were utilized using the same questionnaire sheet.

As for the limitation of the study, The researcher took a long time and great effort to convince women to talk freely or participate in the research. It was preferred that the women who included in the study coming for IUD insertion at first time.

\section{D) Statis tical design:-}

Data were analyzed using statistical package for social sciences (SPSS). Data were presented using descriptive statics in the form of frequencies and percentages for qualitative variables, in addition to means and standard deviations for quantitative variables. Quantitative continuous data were compared using paired t- test in case of comparison between two groups, levene's test for Equality of Variances. To assess the relation between scores of continuous use of IUD as dependent factor, on the other hand, and various quantitative factors, as independent factors binary logistic regression was used, and analysis of variance for the full regression models were done. The data collected were organized, categorized, tabulated and analyzed by using the computer. Statistical significance was considered at $\mathrm{p}$ - value $<0.05$. 


\section{RESULTS:}

Table (1): Presents distribution of the studied women according to their sociodemographic characteristics. It revealed that the mean age of the subjects for the control group was $28.9 \pm 5.49$ years with the highest percentage (64\%)was between 20 to 30 years of age and the mean age of the study group was $29.5 \pm 6.25$ with $(64 \%)$ was less than 20 years of age. More than half of the both study and control group had secondary or diplom education (58\% and 56\% respectively).Majority of women in both groups were housewives.

Table (2): shows the women's previous use of IUD and Causes of its discontinuation, (63\%) of women in the study group previously used IUD compared with (56\%) of women in the control group. The most common cause for discontinuation was need baby in both groups study and control (45\% and $46 \%$ respectively), followed by method related reasons such as IUD expulsion by (10\%)for the study group and ( $8 \%$ ) for the control group, pain by $(3 \%)$ for the study group and $(2 \%)$ for the control group. ps = $(0.372,0.015$ respectively), there is statistically significant difference between the two groups was detected as related to reasons for discontinuation.

Table (3): presents comparison between pre and post counseling of women knowledge regarding IUD, there is significant difference in women knowledge regarding IUD pre and post counseling where Sig. $=.000)$ at $\mathrm{p}$-value .05 .

Table (4): presents comparison between study and control groups regarding IUD uses after counseling, The majority of women in both the study group and control group Continuous use of IUD(96\% and 90\% respectively), while the rest of the women were removed the IUD, half of women $(50 \%)$ in the study group were removed the IUD due to Travel of husband and (40\%) in the control group discontinued due to side effect. From this table, it can clearly be seen that, there are highly significance difference in all items related to IUD uses except in item of Continuous use of IUD.

Table (5): presents the relationship between women's demographic data and continuation rate of IUD for control group, continuation of IUD more likely to occur as the chance of being educated was increased. Unlike that every decrease in age and work associated with increase in IUD continuation.

Table (6): Relationship between women demographic data and continuation rate of IUD for the study group, This table illustrate that, continuation of IUD more likely to occur as the chance of being educated was increased but the decrease in age and occupation associated with increase in IUD continuation. 
Port Said Scientific Journal of Nursing

Vol.8, No. 2, June 2021

Table(1): Distribution of the studied sample according to socio-demographic characteristics

\begin{tabular}{|c|c|c|c|}
\hline $\begin{array}{l}\text { Socio-demographic } \\
\text { characteristics }\end{array}$ & $\begin{array}{l}\text { control group } \\
(n=50)\end{array}$ & $\begin{array}{l}\text { study group } \\
(\mathrm{n}=100)\end{array}$ & P- value \\
\hline Age (years) & & & \\
\hline $\begin{array}{l}<20 \text { years } \\
20 \text { to } 30 \text { years } \\
>30 \text { years }\end{array}$ & $\begin{array}{l}1(2 \%) \\
32(64 \%) \\
17(34 \%)\end{array}$ & $\begin{array}{l}64(64 \%) \\
2(2 \%) \\
34(34 \%)\end{array}$ & 0.002 \\
\hline " Mean \pm SD & $28.9 \pm 5.49$ & $29.5 \pm 6.25$ & \\
\hline $\begin{array}{l}\text { Educational level } \\
\text { Illiterate } \\
\text { Secondary ordiplom } \\
\text { University }\end{array}$ & $\begin{array}{l}9(18 \%) \\
28(56 \%) \\
13(26 \%)\end{array}$ & $\begin{array}{l}9(9 \%) \\
58(58 \%) \\
33(33 \%)\end{array}$ & 0.222 \\
\hline $\begin{array}{l}\text { Occupation } \\
\text { Yes } \\
\text { No }\end{array}$ & $\begin{array}{l}5(10 \%) \\
45(90 \%)\end{array}$ & $\begin{array}{l}4(4 \%) \\
96(96 \%)\end{array}$ & 0.145 \\
\hline total & $50(100 \%)$ & \multicolumn{2}{|c|}{$\overline{100(100 \%)}$} \\
\hline
\end{tabular}


Table (2): Comparison between study group and control group according to previous IUD and causes of removing it

\begin{tabular}{|c|c|c|c|}
\hline variables & Control group & Study group & P-Value \\
\hline $\begin{array}{l}\text { Previous IUD } \\
\text { Yes } \\
\text { No }\end{array}$ & $\begin{array}{l}28(56 \%) \\
22(44 \%)\end{array}$ & $\begin{array}{c}63(63 \%) \\
37(37 \%)\end{array}$ & 0.372 \\
\hline $\begin{array}{l}\text { If yes, causes of removal } \\
\text { Uterine inflammation } \\
\text { Pain } \\
\text { Want to get pregnant } \\
\text { Husband travel } \\
\text { IUD expulsion } \\
\text { Bleeding }\end{array}$ & $\begin{array}{l}- \\
1(2 \%) \\
23(46 \%) \\
- \\
4(8 \%) \\
-\end{array}$ & $\begin{array}{l}2(2 \%) \\
3(3 \%) \\
45(45 \%) \\
1(1 \%) \\
10(10 \%) \\
2(2 \%)\end{array}$ & 0.015 \\
\hline Total & $50(100 \%)$ & $100(100 \%)$ & \\
\hline
\end{tabular}

Table 3 Comparison between pre and post counseling women 'knowledge regarding IUD

\begin{tabular}{|c|c|c|c|c|c|}
\hline \multirow[t]{2}{*}{ Knowledge about IUD } & \multicolumn{2}{|c|}{ Pre knowledge $(\mathrm{N}=100)$} & \multicolumn{2}{|c|}{ Post knowledge $(\mathrm{N}=100)$} & Sig. \\
\hline & Correct & not correct & Correct & not correct & \\
\hline$\overline{\text { Definition of IUD }}$ & "11(11\%) & $89(89 \%)$ & $89(89 \%)$ & "11(11\%) & 0.000 \\
\hline Types of IUD & $16(16 \%)$ & $84(84 \%)$ & $98(98 \%)$ & $2(2 \%)$ & 0.000 \\
\hline Action of IUD & $11(11 \%)$ & $89(89 \%)$ & $93(93 \%)$ & $7(7 \%)$ & 0.000 \\
\hline Advantages of IUD & $71(71 \%)$ & $29(29 \%)$ & $100(100 \%)$ & - & 0.000 \\
\hline Side effect of using IUD & $87(87 \%)$ & $13(13 \%)$ & $100(100 \%)$ & - & 0.000 \\
\hline Time of IUD insertion & $82(82 \%)$ & $18(18 \%)$ & $100(100 \%)$ & - & 0.000 \\
\hline Time of IUD checkup & $23(23 \%)$ & $77(77 \%)$ & $98(98 \%)$ & $2(2 \%)$ & 0.000 \\
\hline Total & 301(43\%) & 399(57\%) & "678(96.8\%) & $22(3.14 \%)$ & \\
\hline $\begin{array}{lll}\text { Total } & \text { Knowledge( } & \text { mean } \\
\pm \text { SD }) & & \\
\end{array}$ & & $3.1 \pm 1.31$ & & $6.8 \pm 0.53$ & $\overline{\overline{0.000}}$ \\
\hline
\end{tabular}


Table (4): Comparison between study and control groups regarding IUD uses after counseling

\begin{tabular}{|c|c|c|c|}
\hline Item & $\begin{array}{l}\text { control group } \\
(n=50)\end{array}$ & $\begin{array}{l}\text { study } \\
\text { group } \\
(n=100)\end{array}$ & $P$ value \\
\hline $\begin{array}{l}\text { Continuous use of IUD } \\
\text { Yes } \\
\text { No }\end{array}$ & $\begin{array}{l}45(90 \%) \\
5(10 \%)\end{array}$ & $\begin{array}{l}96(96 \%) \\
4(4 \%)\end{array}$ & 0.145 \\
\hline $\begin{array}{l}\text { If no, causes of stopping use of IUD } \\
\text { Travel of husband } \\
\text { Want to get pregnant } \\
\text { IUD expulsion } \\
\text { side effect } \\
\text { husband refuse }\end{array}$ & $\begin{array}{l}- \\
1(20 \%) \\
1(20 \%) \\
2(40 \%) \\
1(20 \%)\end{array}$ & $\begin{array}{l}2(50 \%) \\
1(25 \%) \\
1(25 \%) \\
-\end{array}$ & $0.000 *$ \\
\hline $\begin{array}{l}\text { Use of other family planning method } \\
\text { Yes } \\
\text { No }\end{array}$ & $\begin{array}{l}3(60 \%) \\
2(40 \%)\end{array}$ & $\begin{array}{l}1(25 \%) \\
3(75 \%)\end{array}$ & $0.000 *$ \\
\hline $\begin{array}{l}\text { Family planning method used } \\
\text { Capsule } \\
\text { Injection }\end{array}$ & $\begin{array}{l}2(66.7 \%) \\
1(33.3 \%)\end{array}$ & $1(100 \%)$ & $0.000 *$ \\
\hline
\end{tabular}


Table (5): Relationship between demographic data and continuation of IUD for control group

\begin{tabular}{|c|c|c|c|c|}
\hline \multirow[t]{2}{*}{$\begin{array}{c}\text { Socio- } \\
\text { demographic } \\
\text { characteristics } \\
\end{array}$} & \multicolumn{2}{|c|}{ Continuous IUD use $(\mathrm{N}=50)$} & $\mathbf{X}^{2}$ & P-value \\
\hline & Yes & $\overline{\text { No }}$ & & \\
\hline $\begin{array}{l}\text { Age }(\text { years }) \\
\leq 20 \text { years } \\
21 \text { to } 30 \\
31 \text { to } 40 \\
\end{array}$ & $\begin{array}{l}3(6 \%) \\
30(60 \%) \\
17(34 \%) \\
\end{array}$ & $\begin{array}{l}1(2 \%) \\
3(6 \%) \\
1(2 \%) \\
\end{array}$ & 23.016 & 0.149 \\
\hline $\begin{array}{l}\text { Educational level } \\
\text { Illiterate } \\
\text { Secondary } \\
\text { diplom } \\
\text { University } \\
\end{array}$ & $\begin{array}{l}7(14 \%) \\
26(52 \%) \\
11(22 \%)\end{array}$ & $\begin{array}{l}2(4 \%) \\
2(4 \%) \\
1(2 \%)\end{array}$ & 1.751 & 0.417 \\
\hline $\begin{array}{l}\text { occupation } \\
\text { yes } \\
\text { no } \\
\end{array}$ & $\begin{array}{l}5(10 \%) \\
40(80 \%)\end{array}$ & $\begin{array}{l}- \\
5(10 \%)\end{array}$ & 0.617 & 0.432 \\
\hline
\end{tabular}

Table (6): Relationship between women demographic data and continuation rate of IUD for the study group

\begin{tabular}{|c|c|c|c|c|}
\hline \multirow{2}{*}{$\begin{array}{l}\text { Socio-demographic } \\
\text { characteristics }\end{array}$} & \multicolumn{2}{|c|}{ Continuous IUD use $(\mathrm{N}=\mathbf{1 0 0})$} & \multirow[t]{2}{*}{$\overline{X^{2}}$} & \multirow{2}{*}{$\begin{array}{l}\mathbf{P}- \\
\text { value }\end{array}$} \\
\hline & Yes & No & & \\
\hline $\begin{array}{l}\text { Age }(\text { years }) \\
\leq 20 \text { years } \\
21 \text { to } 30 \text { years } \\
31 \text { to } 40 \text { years } \\
>40 \text { years }\end{array}$ & $\begin{array}{l}3(3 \%) \\
57(57 \%) \\
29(29 \%) \\
7(7 \%)\end{array}$ & $\begin{array}{l}- \\
4(4 \%) \\
- \\
-\end{array}$ & 2.664 & 0.446 \\
\hline $\begin{array}{l}\text { Educational level } \\
\text { Illiterate } \\
\text { Secondary or diplom } \\
\text { University }\end{array}$ & $\begin{array}{l}8(8 \%) \\
56(56 \%) \\
31(31 \%)\end{array}$ & $\begin{array}{l}1(1 \%) \\
2(2 \%) \\
1(1 \%)\end{array}$ & 1.282 & 0.527 \\
\hline $\begin{array}{l}\text { occupation } \\
\text { yes } \\
\text { no }\end{array}$ & $\begin{array}{l}4(4 \%) \\
92(92 \%)\end{array}$ & - & 0.174 & 0.677 \\
\hline
\end{tabular}




\section{DISCUSSION:}

Attention to reproductive health and family planning services to promote health and reduce maternal and fetal mortality rates is increasing today. However, according to the WHO statistics, seventy-five million unintended pregnancies occur each year due to the failure or lack of continuous use of contraceptive methods (Zareban et al., 2015).

This study will discuss the result in frame of study hypothesis; Women who get counseling of IUD has longer continuation rate of using than those who don't.

The present study revealed that mean age of women was $28.9 \pm 5.49$ years and there is negative influence of age on the continuation rate of IUD which meaning ; decrease in age associated with increase in IUD continuation of use. In this respect (Tirfe, 2013) found that IUD was used by women of almost all reproductive age groups with the highest number in the age group of (twenty-four to thirty-four) year.

Furthermore, the present study reveals that more than half of women in both control and study group were Secondary or diplom also majority of them were housewives. There is a positive influence of education on the continuation rate of IUD and negative influence of working which meaning; continuous use of IUD more likely to occur as the chance of being housewife and being educated increased. This is opposite to (Castle and Askew, 2015) Women who have worked in the past year are less likely to discontinue than those who have not worked, presumably because they desire to maintain employment rather than have an unintended pregnancy.

Concerning the continuation rate of IUD after six months from counseling, the present study findings demonstrated that no significant differences was found between both control and study group ; the majority of women in both groups continued use of IUD. This is due to the fact that Egyptian women prefer using it over any other method. The higher rate of IUD use in our population related to its image as (a safe, effective, inexpensive and long acting method which is independent of coitus). This in line with (El-Zanaty and Way, 2009) who showed that more than half of currently married women in Egypt are using contraception. The IUD, pill, and injectable are the most widely used methods.

At first glance; in the present study, the counseling has no effect on the continuation rate, But in fact there is an effect where it was improvement in the women's knowledge after receiving counseling which enough to maintain the adherence of 
women to the selected contraceptive method. Before counseling; There was a lack of knowledge on benefits, side effects and complications of IUD among women and these were to some extent associated with some misconceptions expressed during the study such as; it travels through the body.

Also when comparing the present findings with the women's previous history of IUD use; we found that more than half of women in control group and two third of women in the study group were used IUD as a contraceptive method and the main cause for discontinuation in both groups was desire a pregnancy followed by side effect and method failure. While the present study revealed that; a highly significance difference between the study group and control group regarding the reason for discontinuation , half of women in the study group discontinued due to husband travel, quarter of them due to pregnancy and the other quarter due to method failure. This in contrast with the control group; the main cause was side effect followed by pregnancy, husband refuse and method failure. According to this findings; the side effect cause was disappeared from the study group and still high in the control group which reflect the effect of counseling on the continuation rate of IUD.

This in agreement with (Robabi , 2016) as the continuation rate of IUD use in the first six months was more than three quarters.

Finally, concerning women's shifting to another method after discontinuation; the present study revealed high significance differences between the control and the study group where three quarters of sample in the study group don't use any methods and only one quarter of women used implant. While two thirds of the control group shift to another method, almost two thirds used implant and one third of them used injection.

From the above mentioned results; it is obvious that all women who discontinued IUD in the control group shift to another method which mean women UN satisfaction with IUD. Unlike that; only one woman in the study group shift to another method due to IUD expulsion and the rest don't use any other method which mean satisfaction with IUD and this reflect that counseling has an obvious effect on the selection and continuation of the method. 


\section{CONCLUSION:}

Based on study findings, it can be concluded that:

Women showed knowledge deficit about IUD at the pre- counseling phase. Introducing counseling was associated with statistically significant improvement in women's knowledge regarding IUD. The factors that have a positive effect on IUD continuation are education, number of gravida, parity and occurrence of abortion. Husband's opinion has an effect on the selection and continuation of a method.

\section{RECOMMENDATIONS:}

Based on the results of the present study, the following recommendations were suggested:

- There is need to provide counseling to the women about switching to any suitable contraceptive method of their choice, in case they get IUD removed.

- Further studies should be conducted to appreciate and catalogue the effect of counseling on reducing the rate of IUD discontinuation with larger sample and longer period.

- Comparative study should be done between married and unmarried men at age of 20 to 30 years old to assess their knowledge and attitude toward contraceptives.

\section{REFERENCES:}

Ali, M., Cleland, J., and Shah I., (2012): Causes and consequences of contraceptive discontinuation: evidence from 60 Demographic and Health Surveys. Geneva: World Health Organization.

Castle S., and Askew I., (2015): contraceptive discontinuation: reasons, challenges, and solutions population council pp. 1-41.

Castle, S., and Hardtman P., (2015): Supporting International Family Planning Organizations (SIFPO) (Population Services International): Midterm Project Evaluation, A Report to USAID/GH Tech.

Dean G ., Goldberg A (2016): Intrauterine contraception: Devices, candidates, and selection. Available at http://www.uptodate.com 
Egypt Demographic And Health Survey (2014): Ministry of Health and Population, El-Zanaty and Associates Cairo, Egypt, The DHS Program and ICF International Rockville, Maryland, U.S.A. Sep. 11-18.

El-Zanaty F., and Way A.,(2009): Egypt Demographic and Health Survey. Cairo, Egypt: Ministry of Health, El-Zanaty and Associates, and Macro International.pp.451485.

Jain A., Obare F., RamaRao S., and Askew I., (2013): Reducing unmet need by supporting women with met need, International Perspectives on Sexual and Reproductive Health 39(3): 133-141.

Manzouri L., Farajzadegan Z., and Zamani R. A.,(2011):Continuation Rates and Reasons for Discontinuing Tcu380A IUD Use in Isfahan, Iran ; Journal of Family and Reproductive Health Isfahan, Iran. pp. 25-29.

Robabi H., Arbabisarjoul A., Navidian1 A., and Gourkani H., (2016): Scholars research library. Analysis of the Continuation Rates of Intrauterine Device (IUD) and Three-Month Injectable Depot Medroxyprogesterone Acetate (DMPA)Uses and Reasons for Their Discontinuation in Women Referred to Health Centers Available at: http://scholarsresearchlibrary.com/archive.html

Tirfe . B. T.,(2013): A study exploring the socio-demographic and service related factors influencing the utilization of intra uterine contraceptive device among family planning users in Addis Ababa Ethiopia .pp.36- 41.

Zareban I., Robabi H., and Arbabisarjou A., (2015): Contraception counseling and compliance ;7(11):pp. 308-312 available at: www.who.int/entity/bulletin/volumes. 


\section{أثر الإرشاد التمريضي على معدل استمرار استخدام اللولب}

أ.د / رجاء علي عبد ربه، أ.م.د/ سهام شحاتة إبراهيح, د/ نور الهاى محمد السيد، إيمان عبد الفتاح على الهي الأسطى

أستاذ تدريض صحة الأم والوليب ـ كلية التمريض - جامعة القاهرة ـ أستاذ مساعد تمريض الأمومة و النساءو و التواء التوليب ـ كلية التصريض - جامعة بورسعبي - مدرس تصريض الأمومة و النساءو التوليب كلية التصريض- جامعة بورسعبي

\section{الــــلاصـــة}

على الرغم من أن اللولب هو واحد من أكثر وسائل منع الحمل استخدامًا ، إلا أن المضاعفات المصاحبة له مثل النزيف وحدوث الآلام قد تؤدي إلى الإزالة المبكرة في بعض الحالات. تهدف هذه الدراسة إلى تقييم تأثير الإرشاد التمريضي على معدل استمرار استخدام اللولب. أجريت هذه الدراسة الشبه تجريبية من بداية يناير 2017 إلى نهاية

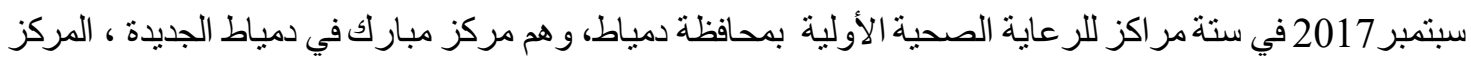
الطبي في دمياط الجديدة ، ألسنانية في دمياط ، المنتزه في دمياط ، حي أول وحي ثناني في دمياط. وقد اشتملت عبن عينة البحث على (150) سيدة أتت لأحد المر اكز السابق ذكرها لتركيب لولب. وقد نم جمع البيانات عن طريق استخدام؛

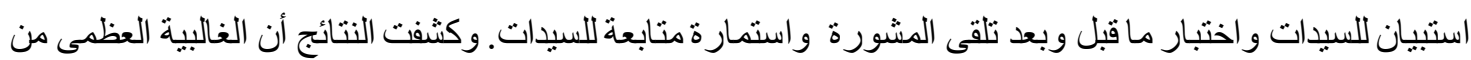
النساء في كل من مجموعة الدراسة والضابطة (96 \%) و (90 \%) على التوالي استمروا في استخدام اللولب. فحين أن نصف النساء (50\%) في مجموعة الدراسة توقفن بسبب سفر الزوج ، ربعهن (25\%) بسبب الحمل والربع الآخر (25\%) بسبب فثل الوسيلة. هذا على النقيض من مجموعة الضابطة ؛ حيث كان السبب الرئيسي هو الآثار الجانيية

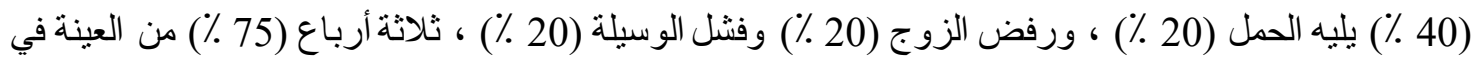

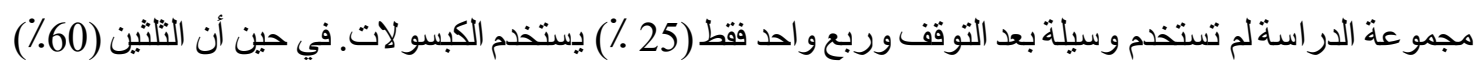

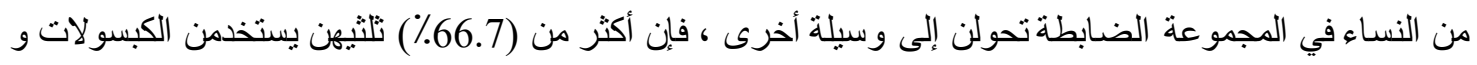
التلث الأخر (33.3٪) منهن يستخدمن الحقن . استنادا إلي هذه النتائج يمكن أن نستخلص انه؛ قد واصلت غالبية النساء في كل من مجموعة المر اقبة و الدراسة استخدام اللولب بعد ستة أشهر من تلقي المشورة. وكان السبب الرئيسي للتوقف

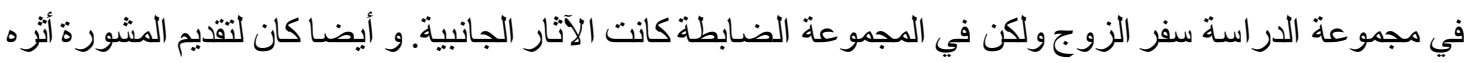

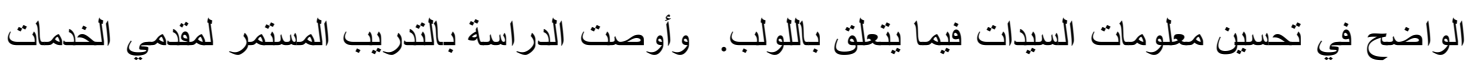

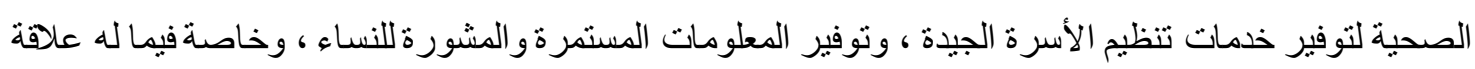

بالآثار الجانبية.

الكلمات المرشدة : اللولب؛ إيقاف الاستخدام؛ الإرشاد؛ الحمل الغير مقصود. 